переживания музыки и смысловой определенности её интонационного словаря. Так, среди основного утраченного смысла музыки оказывается красота и ясность музыкального выражения, которые становятся основными интенциями композиторского творчества, репрезентующего стилевую тенденцию «новой простоты», и обусловливающие централизацию консонанса в системе музыкального языка того или иного композитора и принцип простой фактуры, обеспечивающий «прозрачность» музыкального смысла посредством «открытости» первоэлементов музыкального языка (мелодии, ритма и гармонии).

Еще один уровень «нового» в «новой простоте» проявляется не столько в музыкально-технологической плоскости, сколько в концептуальной - в самом композиторском понимании новизны как необходимого фактора музыкального творчества. Это понимание заключается в отказе от авторского «маркера» музыкального языка, а также в принципе манипулирования «словарным запасом» прошлых эпох европейского музыкального искусства, что априори порождает интертекстуальные свойства музыкального текста и его диалогический смысл.

DOI https://doi.org/10.30525/978-9934-26-004-9-129

\title{
УКРАЇНСЬКЕ ЦЕРКОВНО-МОНОДИЧНЕ МИСТЕЦТВО У ВІТЧИЗНЯНИХ РУКОПИСНИХ ДЖЕРЕЛАХ КІНЦЯ XVI - XVIII CT.
}

\author{
Путятицька О. В. \\ кандидат мистеитвознавства, доиент, \\ в.о. професора кафедри історії української музики \\ та музичної фольклористики \\ Національної музичної академії України імені П. І. Чайковського \\ м. Київ, Україна \\ Українське церковно-монодичне мистецтво кінця XVI - поч. XVII ст. \\ відзначається неймовірним кульмінаційним злетом. Водночас, зі стійким \\ побутуванням одноголосся, у період з кінця XVII - XVIII ст. домінує вже \\ українська духовна багатоголосна музика, що за своїм високим художнім \\ рівнем не поступалась тогочасній західноєвропейській бароковій музиці.
}


Церковні піснеспіви цього періоду зафіксовані в нотованих джерелах - Ірмолоях. Це основна рукописна нотолінійна книга, яка вміщала весь річний церковно-співацький репертуар (від вересня до серпня), який виконувався в Україні та Білорусії. Вона сформувалася в Україні в період XIV - XVI ст. У невеликій кількості до нашого часу дійшли найдавніші Ірмолої з кінця XVI - початку XVII ст., а від XVII XVIII ст. їх зберіглася велика кількість із різних територій України. Протягом кінця XVI - XVIII ст. в Україні були зроблені численні списки нотолінійних Ірмолоїв (понад тисячу), що свідчить про широке використання в цей час у церквах монодії паралельно з багатоголосою церковною музикою. Значне місце в цій книзі займає жанр ірмос, звідси і походить назва збірника. Але в Ірмолой увійшли також співи зі Всенічної Служби, Літургії; догматики з богородичними, сідальні, степенніантифони, кондаки, канони, тропарі, стихири та інші [5, с. 5].

Вивченням структури Ірмолоїв, їх палеографічним описом, каталогізацією займався музикознавець Ю. Ясиновський [10], який встановив, що в Україні сформувався своєрідний український тип церковно-співочої книги. У структурі Ірмолоїв поєднувалися різні принципи: жанровий, гласовий та календарний. Ірмолой складається 3 таких основних розділів:

- на початку збірника є деякі важливі співи цілодобового богослужіння: Всенічна, Літургія, окремі перемінні співи Утрені та інші доповнення;

- у центральному і найбільшому розділі є ірмоси, до яких у кожному гласі додані найважливіші співи недільного богослужіння Октоїха (догматики з богородичними, сідальні, степенні-антифони);

- наступну велику групу становлять стихири на вибрані свята всього року, сюди ж у порядку розміщення церковного календаря приєднані деякі найважливіші співи Пісної і Цвітної Тріоді;

- невеликий розділ у системі восьми гласів становлять подібні стихирам.

Ірмолої переписували переважно в монастирях (Києво-Печерському, Межигірському, Манявському та інших), а також в інших культурних осередках, причому у збірниках часто вказується церква, храм або монастир, у яких переписувався або складався рукопис. Переписувачами були не лише ченці та дяки, але й світські люди. Кожний переписувач, зберігаючи традиції, використовував специфічні прийоми в організації аркуша: розміщення поля тексту, розлініювання, розміщення нотних рядків, покажчиків, титулів, колонтитулів [4, с. 21]. До переписування цих збірників ставилися дуже відповідально, бо вважали це богоугодною 
справою. Ноти та словесний текст писали дуже каліграфічно, яскраво оформляли ініціальні літери. Часто вставляли мініатюри із зображенням святих (так, наприклад, акварельне зображення св. Іоанна Дамаскіна - у Жировицькому Ірмолої у стародрукованій вирізаній та наклеєній на аркуш рамці [1, арк. 48 зв.]; у Львівських Ірмолоях [2, арк. 32 зв.; 3 , арк. 70 зв.]. Крім того, кожний розділ починався орнаментальною заставкою 3 плетінчатого та рослинного орнаменту 3 характерним використанням соковитих кольорів, що носить яскраво виражені ознаки українського бароко з відчутнім впливом народних традицій. Типовими $\epsilon$ записи переписувачів, які фіксували час і місце створення, свої імена та імена своїх покровителів та свідків. Деколи текст супроводжується припискою з погрозами про страшні кари за викрадення рукопису. Інколи на полях книги робили і побутові записи, де поряд з приписками про придбання рукопису є записи про ціни на жито, пшоно, особисті записи польською та українською мовами, проби пера та інше. Перші друковані Ірмолої з'явилися у Львові в 1700 та в 1709 році. Але й на далі існувала традиція переписування цих збірників.

Основний зміст Ірмолоїв українського походження складала давньоукраїнська церковна монодія, яка розвивалась на традиціях старокиївського співу. Переписувачі українських нотолінійних Ірмолоїв часто робили дописки на полях біля окремих піснеспівів: "напһль"1 київський, межигірський, острозький, львівський, волинський, а також болгарський, сербський, грецький та ін. Але найраніше з'явилася позначка "болгарського" наспіву ("напһль болгарский", "ноти болгарской”, або скорочено "бол."), яка зафіксована у найдавніших збірниках кінця XVI - початку XVII ст. [6, с. 145].

Сумарний склад піснеспівів в Ірмолоях українського та білоруського походження 3 атрибуцією "болгарський" у кількісному відношенні значно перевищує кількість піснеспівів, які фіксуються у цих рукописах з іншими позначками ("київський", "межигірський”, "грецький", "сербський" та ін.). Отже, піснеспіви болгарського наспіву, що містяться в Ірмолоях з бібліотек Києва та Львова, як дослідила Л. Корній, становлять неповний корпус збірника річних недільних і святкових співів різних жанрів, але розпорошених по різних Ірмолоях. Встановлення наявності в співочій практиці України розосередженого збірника болгарського наспіву типу Ірмолоя, який при текстовій схожості має інший мелодичний зміст - один 3 найважливіших доказів

${ }^{1}$ Церковнослов'янське слово "напһль" передається українською мовою як "наспів", а не "розспів".

232 
того, що болгарський наспів в співочій практиці України складає самостійне відгалуження богослужбового співацького мистецтва. Переписувачі Ірмолоїв фіксували неоднакову кількість болгарських наспівів: в одних рукописах містяться поодинокі піснеспіви, а в інших десятки зразків [7].

Вивченням репертуару болгарського наспіву, та його особливостей поширення в українській співацькій практиці на великому джерельному матеріалі займались вітчизняні дослідники Л. Корній [7] та О. Путятицька [8].

Піснеспіви в Ірмолоях записані п'ятилінійною київською квадратною нотацією ("київське знам'я"), якою стали записувати церковні монодичні співи після реформи нотного запису в Україні у другій половині XVI ст., а вже з кінця XVI ст. вона стала використовуватися і в Білорусії. На початку кожного рядка на одній із лінійок (першій, третій, рідше на четвертій) стоїть ключ, який має форму латинської літери С. Він вказує на місце знаходження звуку $c$ першої октави. 3 приключових знаків фіксується лише один бемоль (сі-бемоль). Інколи з'являються додаткові бемолі, що спричиняє певні труднощі при прочитанні піснеспівів. Вивченням цієї проблеми займалася музикознавець О.Цалай-Якименко [9]. Вона вказує, що абсолютну висоту звука задавав ключ на початку нотного стану, а в середині виникали бемолі внаслідок релятивного методу співу. Знак релятивного бемоля вказував верхній звук півтону. Внаслідок релятивного методу співу при переході в інший гексахорд, який завжди мав стабільну структуру $(1 \mathrm{~T}, 1 \mathrm{~T}, 1 / 2 \mathrm{~T}, 1 \mathrm{~T}, 1 \mathrm{~T})$ виникали додаткові бемолі.

Порівняно з сучасною нотацією київська п'ятилінійна нотація дещо відрізнялась у позначенні ритмічних тривалостей нот, які мали такий вигляд:

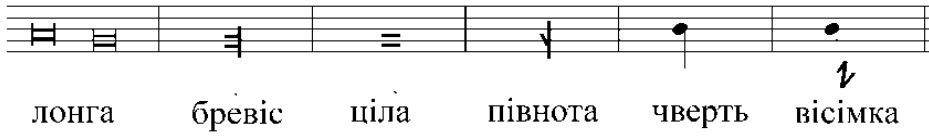

У зв'язку з тим, що наспіви мали нерегулярну часокількісну ритміку, в рукописах не позначався метр i не ставились тактові риски. Переписувачі не фіксували ліг і темпових позначень.

Мова словесних текстів піснеспівів $€$ церковнослов'янська, але 3 помітними фонетичними та лексичними впливами староукраїнської мови XVI - XVII ст. Дуже часто в текстах зустрічається плутанина літер $\mathbf{b}-\mathbf{i}$, и - ы, зрідка - в - л у закінченнях дієслів, позначення твердості р та шиплячих. 
Українські нотолінійні Ірмолої, в яких фіксувався болгарський наспів, функціонували в українській співочій практиці упродовж тривалого історичного періоду, тому цілком очевидно, що вони й досі викликають живий інтерес у дослідників.

\section{Література:}

1. Бібліографічний опис рукопису: шифр I, 3367, Перший відділ (ф. I), Центральна Наукова бібліотека імені Вернадського НАН України, Інститут рукописів, Київ. Арк. 48 зв.

2. Бібліографічний опис рукопису: шифр Ф. 2, № НД - 103, Львівська національна наукова Бібліотека України імені В. Стефаника, Відділ рукописів. Львів. Арк. 32 зв.

3. Бібліографічний опис рукопису: шифр Ф. 2, № НД - 123, Львівська національна наукова Бібліотека України імені В. Стефаника, Відділ рукописів. Львів. Арк. 70 зв.

4. Дубровіна Л. А. Кодикологічне дослідження та археографічний опис нотолінійних ірмолоїв. Л. П. Корній, Л. А. Дубровіна. Болгарський наспів 3 рукописних нотолінійних Ірмолоїв України. - К. : НБУ ім. В. І. Вернадського, 1998. С. $18-38$.

5. Корній Л. П. Болгарський наспів у церковно-співацькій практиці України кінця XVI - XVII ст. Л. П. Корній, Л. А. Дубровіна. Болгарський наспів 3 рукописних нотолінійних Ірмолоїв України. - К.: НБУ ім. В. І. Вернадського, 1998. С. 5 - 17.

6. Корній Л. Історія української музики. К. -Харків - Нью-Йорк: видавництво М. П. Коць, 1996. Ч. 1.314 с.

7. Корній Л. П. Болгарський наспів в співочій практиці України XVI - XVII ст. : дис. ... кандидата мистецтвознавства: 17.00.03. К., 1980. $-155 \mathrm{c}$.

8. Путятицька О.В. Болгарський наспів і українсько-білоруська традиція церковного монодичного співу кінця XVI - XVIII ст. (джерелознавче i порівняльно-стильове дослідження): дис. ... канд. мистецтвознав.: 17.00.03. Нац. муз. акад. України ім. П.І. Чайковського. К., 2009. 267 c.

9. Цалай-Якименко О. Київська нотація як релятивна система (за рукописами XVI - XVII ст.). Українське музикознавство : Науковометодичний збірник. К. : Музична Україна, 1974. Вип. 9. С. 197 - 224.

10. Ясиновський Ю. Українські та білоруські нотолінійні Ірмолої 16 18 ст. Львів : інститут українознавства ім. Крип'якевича НАН України, видавництво Отців Василіан «Місіонер», 1996. Серія : Історія української музики. Вип. 2 : Джерела. 624 с. 